\title{
FACTORS OF ECONOMIC DYNAMISM IN ASIAN COUNTRIES
}

\author{
George Cornel Dumitrescu ${ }^{1}$
}

\begin{abstract}
The aim of this paper is to identify the factors that determined economic growth in Asian countries. In order to understand these factors and how they joined forces to help acquire economic growth, the paper studied some of the most relevant economies from this dynamic area of the world.

The study identified capital accumulation, education, technological transfers, foreign investments, state interventions in shaping a sound economy and natural resources as important factors of growth, along with the cultural heritage of Asian people.
\end{abstract}

Keywords: economic growth, human capital, foreign investment, education, culture

JEL codes: O14, O15, O16, R11,

\section{Introduction}

During the last decades of the $20^{\text {th }}$ century, Eastern Asian countries have displayed an outstanding record of high and sustained economic growth. The most emblematic countries in this regard were Japan, Singapore, Hong Kong, Korea, Taiwan, Indonesia, Malaysia, and Thailand, most being newly industrializing economies.

The outstanding economic change on the Asian continent has been subject to many studies and many economists tried to identify the features that made the difference in the very complex economic environment from which these countries emerged. The objective of this paper is to identify the factors which generated economic growth in Asia and find out if there are any common denominators in this regard. The focus was placed on Japan, China, India, Kazakhstan, Vietnam and Pakistan, countries which differ in cultural, social and economic background. Analyses of well known economists were used to ponder some of the working hypothesis.

\section{General overview}

The "miraculous" growth of the Asian countries was driven by the presence of several very important factors: capital accumulation, efficient allocation, rapid technological progress, education, strong institutions, openness to foreign technology and foreign investments. This is clear in the study below.

Domestic savings and investments in the high-performance East Asian economies are significantly higher than in other economies. Saving rates for East Asian economies averaged about 35 percent of GDP, while the saving rate in Sub-Saharan Africa was 15 percent, in Latin-America and the Caribbean 19 percent, and in the high-income economies 20 percent (1).

The main focus of the Asian countries was to transform their economies from being dependent on export-oriented manufacturing to becoming knowledge-based economies. They developed their technological capability via their well functioning national innovation system, namely in science and technology.

\footnotetext{
${ }^{1}$ Top SAFARI SRL, Romania, e-mail: george.dumitrescu@topsafari.ro
} 


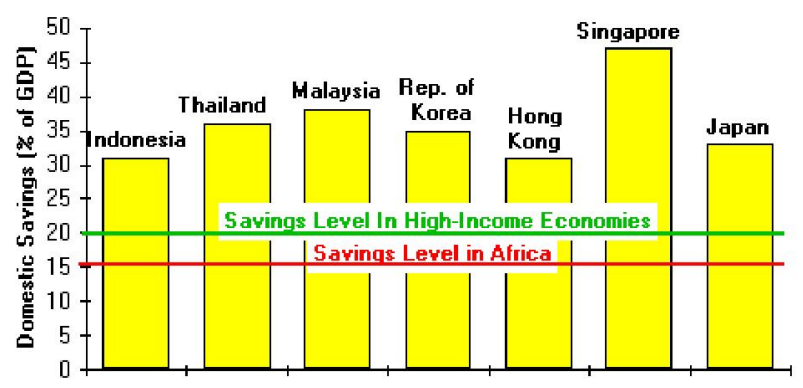

Fig. no.1. - Economic Growth in East Asia High Savings and Investment

Note: Data are for 1993. Levels for Africa (Sub-Saharan) and high-income countries (World Bank classification) are weighted averages.

Source: http://www.galbithink.org/topics/ea/save.htm, 10.07.2011.

In this endeavor, on the one hand, Asian countries put emphasis on government incentives and supports for reducing the risks of firms that invest in innovation, and stimulated $R \& D$ investment for science and technology, and on the other hand, the spillover of know-how from multinationals.

To reduce the technology gap rapidly, buying only technology would not be enough. In order to be attractive to foreign technology transfers, the East Asian economies realized that they had to make big investments in human capital.

In Singapore, Krugman (1994) says that: "The employed share of the population surged from 27 to 51 percent. The educational standards of that work force were dramatically upgraded: while in 1966 more than half the workers had no formal education at all, by 1990 two-thirds had completed secondary education. Above all, the country had made an awesome investment in physical capital: investment as a share of output rose from 11 to more than 40 percent."

ASEAN-4 (Indonesia, Malaysia, Philippines, and Thailand) countries were subject to major foreign direct investment (FDI) in the late 1980s. This was due to the fact that firms from Japan and the newly industrializing economies were looking for production bases abroad to escape appreciating home currencies and the loss of preferential access to many OECD markets.

China and Vietnam also attracted solid foreign investment due to cheap labor. FDIs in China have recently been three times as high as those in the ASEAN-4 combined.

The Asia-Pacific region emerged from the global financial crisis as a growth driver and an anchor of stability for the global economy. As per Singh Anoop (2011), economic growth averaged 8.3 percent across the region in 2010, on the back of both strong exports and domestic demand. Asian exports, especially of high-tech products, have benefited from higher global investment, and domestic consumption and investment from rising employment, abundant credit, and supportive macroeconomic policies. Growth is likely to remain robust, averaging 7 percent in both 2011 and 2012 (compared to 4.5 percent global growth). China and India will remain in the lead, and their growth will increasingly benefit other economies in the region.

Might a cultural component that is unique in Asia be the difference? Might Confucianism be such a possible component? We all admit that the Asians are different. Their commitment to work and certain values is well known all over the world. Patriotism and the sense of attachment they feel towards the organizations they belong to, might be a very good basis for the economies and societies they proudly built.

Confucius had a great influence on Asian culture. His philosophy started in China and was adopted by Japan. Through these two main streams, Confucianism spread all over Asia. One of the 
most important pillars of Confucianism is ethics. In economic life, ethics is translated as human behavior which doesn't deteriorate relationships among partners or relationships with clients. The Asian countries imported from the western countries their knowledge and technologies, but never their ethics. They promoted in business their own values and the results are visible nowadays. One major cultural difference between Western and Asian countries is that in the Asian countries, the emphasis is placed on collective values, while in the Western countries, focus is on individual values. The Japanese will never admit that the western civilization is superior to their own, but they will recognize the Chinese cultural superiority.

\section{Great economists views on Asia}

Amartya Sen (1997) asked the following question: Does authoritarianism really work so well? It is certainly true that some relatively authoritarian states (such as South Korea, Lee's Singapore, and post-reform China) have had faster rates of economic growth than many less authoritarian ones (such as India, Costa Rica or Jamaica). ... We cannot really take the high economic growth of China or South Korea in Asia as "positive proof" that authoritarianism does better in promoting economic growth-any more than we can draw the opposite conclusion on the basis of the fact that Botswana, the fastest-growing African country (and one of the fastest growing countries in the world), has been an oasis of democracy in that unhappy continent. Much depends on precise circumstances.

In Asian countries there are three kinds of political regimes: liberal democratic pluralism în Thailand and the Philippines, soft, semi democratic authoritarianism in Malaysia and Singapore and pure authoritarianism in Vietnam, Lao and Cambodia. In the Human Development Index for 2007 the countries are ranked as follows: Thailand (87), Philippines (105), Malaysia (66), Singapore (23), Vietnam (116), Lao (133) and Cambodia (137).

Paul Krugman (1994) argued that: "Many, perhaps most, writers on the global economy now take it for granted that the success of these economies demonstrates three propositions. First, there is a major diffusion of world technology in progress and Western nations are losing their traditional advantage. Second, the world's economic center of gravity will inevitably shift to the Asian nations of the western Pacific. Third, in what is perhaps a minority view, Asian successes demonstrate the superiority of economies with fewer civil liberties and more planning than we in the West have been willing to accept."

Joseph Stiglitz (1996) argues: "Capital accumulation is often given credit for being the engine of growth. And the countries of East Asia certainly have accumulated capital at an impressive rate. Sometimes the concept of capital accumulation is broadened to include human capital - the improvement in the skills of the labor force."

For example in Japan, from 1947, students had to study for at least nine years (elementary school and secondary school), most of them attend high school and then university or vocational schools. Acquiring skills during their educational years enabled Japanese workers to rapidly adjust to new technologies and to improve and invent new ones.

Among the growth stimuli in the region, Victor Krasilshchikov underlined: "A rise of the new international division of labor. /.../ intention of the US restrain both the Maoist expansion and the Soviet influence in the region by means of successful capitalist modernization of the American satellites in Asia. The US supported the local elites aimed at building 'good' capitalism instead of peripheral one and endeavored to perform 'the capitalist vitrine' in the region to the world community. Reaching these goals, Uncle Sam delivered the trade preferences to the future 'tigers', in particular, facilitated an access of the exported goods from East Asia to the US market."

Barry Bosworth "et al" (2007) say that: "in recent years, controversy has surrounded the roles of physical capital and education (human capital) in the growth process. Young (1995) has shown the dominance of physical capital accumulation in the growth of the East Asian economies. On the other hand, Klenow and Rodriguez-Clare (1997) argue that physical capital accumulation is 
largely induced by increases in TFP, a phenomenon that leads to an overstatement of the contribution of physical capital as an exogenous source of growth. Easterly and Levine (2001) argue that only a small percentage of the variation in growth across countries could be attributed to capital accumulation. Baier and others (2006) argue the opposite. Our own reading is that both capital accumulation and gains in TFP are important components of the growth process (Bosworth and Collins, 2003), although we agree that the precise magnitude of the role varies across countries."

\section{Japan}

Japan benefited, between 1950 and 1980, from a privileged relationship with the United States due to the Korean and Vietnam War. During this time, Japanese companies had access to American technologies which allowed them to modernize and become world players. During the mentioned wars, Japan took advantage of its strategic position and engaged its economy in supplying the American war effort with all its procurement needs. This was the beginning of the "Japanese Miracle".

The rest was made by skilled human capital, a very stable political system, good management and the cultural background of this great nation.

Jeffrey Hays (2009) says that Japan's economic ascension had three distinct stages. The first stage was guided by the "priority production system" of the 50s that stressed increasing coal and steel output and developing heavy industries like ship building and timber making. In the second stage, in the 60s and 70s, Japan focused on producing consumer products and automobiles for export markets. The third stage was the development of knowledge-based products like computers and electronics.

The excellent economic results of modern Japan in that period reflected the philosophy of its great architect Yukichi Fukuzawa which encouraged his people to rely on themselves and learn all the possible lessons from foreigners without being shamed of copying anything.

Now, Japan is the third largest economy in the world (after the US and China) and inspite of the problems created by the last earthquake and tsunami, doubled by radiation leaks at some of its reactors, Japan still has the strength and knowledge to preserve its position in the world economic top three.

\section{China}

China's strong economic growth has been stimulated by reforms, FDIs, exports and urbanization. Among the most important reforms was the privatization of state-owned enterprises.

FDIs generated an increase in technological support and education. The state invested a huge amount of capital and human resources in developing education and technology. Urbanization proved to be a vital driver of market demand and produced massive investments in infrastructure.

China's economy has grown by an average of almost 10 per cent every year since 1978 . This was the year that China began its transformation from a centrally planned economy which was closed to trade, to one which is more market-orientated and open.

In 2010 Chinese GDP was 62 times bigger than that of 1970, making it the country with the second largest GDP in the world, but when it comes to GDP per capita, in 2010 China recorded 4382 US dollars, ranked 91 in the world, the second position being held by Norway.

Carsten Holtz (2002) mentions that one argument that supporst the idea that past economic growth may continue into the future is that China's economic growth matches standard growth patterns identified by theories of economic development and trade. These are structural change, catching up, and factor price equalization. China's past economic growth fits well with all three.

Another economic booster for the Chinese economy is the foreign exchange reserves which in September 2011 were 3.201 billion USD. Per capita, that means approximately 2500 USD, almost half of the GDP per capita in 2010. Two thirds of these reserves are in US dollars, mostly 
American treasury bonds. The second place is held by Japan with 1.137 .809 million USD. Considering the volatility of the global economy in the context of the current economic crisis, China is forced to ask, on a regular basis, its American counterparts to provide guaranties for these bonds.

\section{India}

India's growth was also impressive during the last decades. Since the early 1980s when it started a program of reform, India's economy has grown by an average rate of almost 6 per cent. The drive of this increase was the strong domestic consumption and investment, increase in employment and the productivity of both capital and labor.

The middle class is growing and so the GDP, exports, employment rate and foreign investments are also increasing.

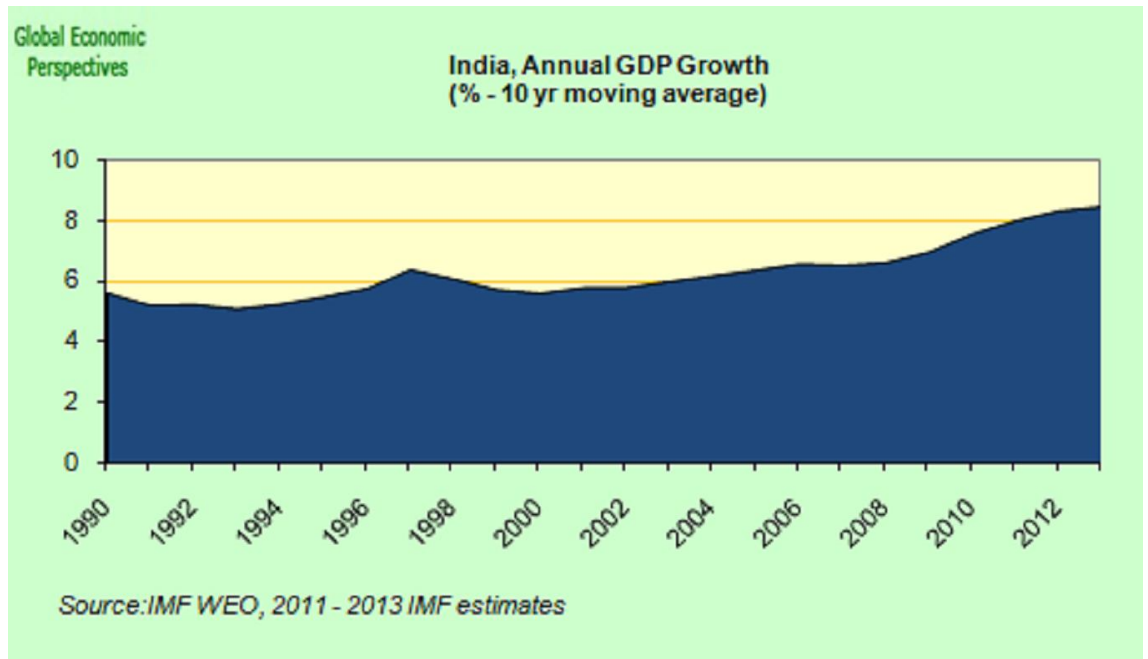

Figure no.2.

Source: India's Economy Hits What Has To Be A Very Welcome "Soft Patch", Author: Edward Hugh, June 19th, 2011, http://www.economonitor.com/edwardhugh/2011/06/19/indias-economy-hits-what-has-to-be-a-very-welcome-softpatch/, 7.07.2011

With a population of 1.210.193.422 in March 2011, India's economic growth is the second largest in the Asian countries $(11,1 \%$ ) and the fourth largest in the world, according to the IMF statistics for 2010. The highest economic growth in Asia was recorded by Singapore $(14,5 \%)$ and it is ranked third in the whole world.

In August 2011, the foreign currency reserves of India were 318 billion USD, ranking it seventh in the world. In 2010, India's GDP was 4,057,787 million USD, the fourth largest in the world, but per capita, around, 1.371 USD, less than half of that of the Chinese. The Indian economy is less affected by the economic crises due to the fact that it doesn't rely as much on exports (over 50 percent of its GDP in domestic consumption) as the Chinese economy.

Rodrik and Subramanian, in an IMF working paper of 2004, pointed out that India seems to have a large amount of productivity growth from relatively modest reforms. A more recent paper by Barry Bosworth, Susan Collins, and Arvind Virmani (2006) has confirmed this. They have concluded that the output per worker grew at 1.3 percent annually during 1960-80 and total factor productivity (TFP) was barely above zero.

Moreover, growth is broadly based on the information and communication technology sector, as well as the manufacturing sector, agriculture and infrastructure. Agriculture and the manufacturing industry represent each approximately $25 \%$ of the GDP, and the ITC around half of it. The automotive industry is growing fast, India being the fourth passenger car producer in Asia and the seventh in the world. 
Finance Minister Palaniappan Chidambaram has reiterated the government's intention to "make financial services the next growth engine for India," including making Mumbai an international financial centre.

\section{Kazakhstan}

Kazakhstan, one of the former Soviet republics, is now an emerging economic star. From 1998, Kazakhstan entered the phase of strong and sustained growth. This was caused by the rapid increase in oil and gas extraction and related activities that very significantly contributed to economic growth as well as to increased government revenue.

From 2000 to 2007, Kazakhstan doubled its rate of economic growth and plans to triple it by 2015. Spending on education and health care have grown more than eightfold. Secondary education is provided to practically $100 \%$ of children. The literacy rate is $99.6 \%$.

Kazakhstan is set to bolster economic growth and entrepreneurial activity by slashing red tape for startups. The government will cut the number of permits and licenses needed to operate businesses by as much as 30 percent. (2) following:

The Strategic Plan 2020, Kazakhstan's Way to Leadership takes into consideration the

1. Prepare the economy to post-crisis development;

2. Achieve sustainable economic development due to expedited industrialization and infrastructure development;

3. Invest actively in the future in order to increase competitiveness of human capital;

4. Provide Kazakhstan's citizens with qualitative social, housing and utility services;

5. Strengthen the interethnic harmony, national security, and further develop international relations. (3)

\section{Vietnam}

Vietnam is the only N-11 (Bangladesh, Egypt, Indonesia, Iran, South Korea, Mexico, Nigeria, Pakistan, the Philippines, Turkey and Vietnam) economy that has managed to maintain growth comparable to that of China and India.

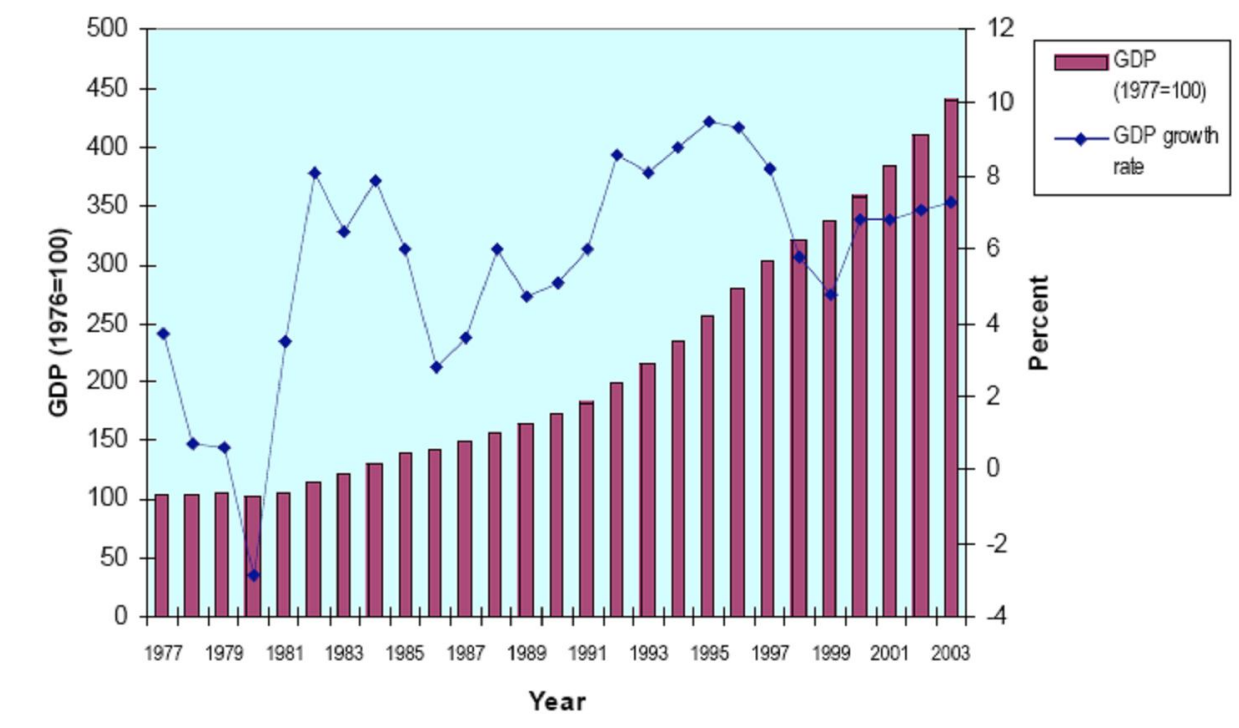

Fig. no. 3. - Economic Growth in Vietnam, 1977-2003

Source: Tran Van Tho et al. (2004) for data to 1999, post 1999 data from CIEM (2005)

Http://www.depocenwp.org/upload/pubs/PhamQuangNgoc/Structural_change_\&_econonmic_perfomance _of_VN_DEPOCENWP.pdf. 
The shift away from a centrally planned economy to a more market-oriented economic model has improved the quality of life for many Vietnamese. Per capita income rose from \$220 in 1994 to $\$ 1,168$ in 2010 . (4)

Between 1995 and 2004 Vietnam grew at a rate of about 7.5 percent per year.

The recent years looked even better. Vietnam's foreign trade is around $\$ 20$ billion per year whereas its total foreign aid is only about \$2 billion per year. In 2003, Vietnam took in foreign investment equal to 8 percent of its GDP. This is a higher proportion of foreign investment than China got.

Doi Moi played a very important role in shifting the Vietnamese economy from a planned economy to a market oriented economy. Government policies were very important and assured the economic structural changes of the economy.

Based on an analysis of changing cost structures and demographic trends, we predict much more rapid growth in Vietnam as a lower cost alternative for much of the labor intensive but low wage production that has migrated to China in recent years. This can come not only from decisions by traditional transnational firms, but also from the globalization of domestic Chinese firms sending FDI into Vietnam.

Vietnam has been very attractive, with respect to investment during the last decades, and there are good prospects that lie ahead. Vietnam also experienced rapid industrialization and urbanization in the wake of its reforms.

\section{Pakistan}

Pakistan is one of the Asian countries that achieved an average growth rate of over 5 percent over the last decades of the last century. In 2010, GDP growth rate was at $4.79 \%$.

Some of its advantages are its self-sufficiency in most food production, a highly diversified base of manufactured products, and good infrastructure (network of gas, power, roads and highways, ports and telecommunication facilities). The largest setback to the country has been the neglect of human development.

At present, the economic situation is difficult in Pakistan. The World Bank, IMF and USA are financing the reforms despite the political instability, due to the country's strategic position in the region.

According to the IMF statistics, in 2010, Pakistan's GDP was 467.197 million USD, placing it $27^{\text {th }}$ in the world. In the same year, per capita GDP was at 1.030 USD.

The infrastructure and an immense young population, doubled by investments in human capital, might be the key in the future development of this country. Pakistan has oil reserves of 6000 million barrels and 19.000 million cubic feet of gas. This "fortune" could be a factor of economic growth or political instability and conflicts, given the situation of the countries having these precious resources.

Pakistan spends almost all its resources on defense and state security, leaving aside little for education. Education can provide the skilled labor required for the new technologies.

Usually, technology is transferred when the recipient country has the capability to operate it, so in order for it to become attractive from this standpoint, the state should create the conditions for better education.

\section{Bangladesh}

Bangladesh is a developing market-based economy. As per the IMF, Bangladesh ranked as the $48^{\text {th }}$ largest economy in the world in 2009, with a GDP of US\$ 256 billion.

Bangladesh economy accelerated around 1990, driven by a combination of macroeconomic stability, openness, and the impact of the ICT revolution. 
As we can see in the chart below, the growth in GDP was generated, among other factors, by investments. The private sector-led development strategy encouraged investments and the government enforced laws and created institutions in order to attract FDIs with an investmentfriendly climate.

The country`s exports and imports accounted for 37 percent of GDP between 2004-2006. This stage is similar to the second period of development between the 60s and 70s in Japan which was also focused on producing economic goods for export markets.

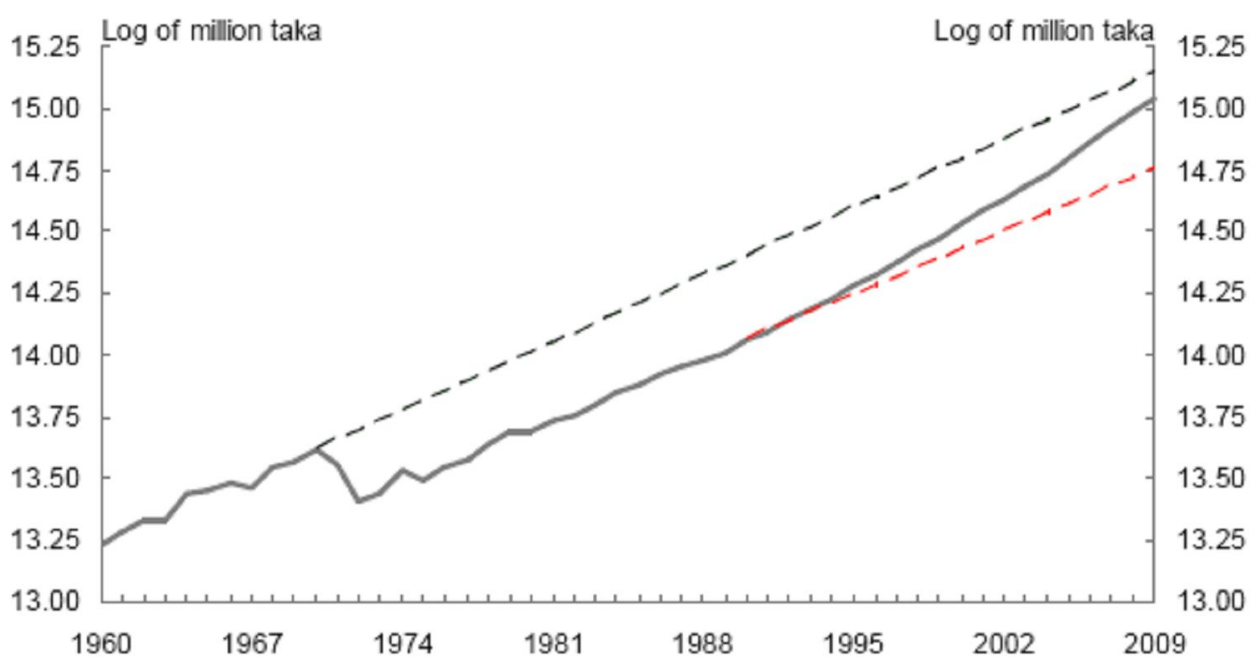

The solid grey line shows actual path of GDP. Dotted lines are hypothetical trend paths based on: 1960s trend (green); 1970s/1980s trend (red).

Source: Bangladesh Bureau of Statistics, World Bank, authors' calculations

Fig. no.4. - Real GDP

Source:

http://www.hks.harvard.edu/fs/drodrik/Growth\%20diagnostics\%20papers/Economic\%20growth\%20in\%20 Bangladesh\%20-\%20experience\%20and\%20policy\%20priorities.pdf. p. 1. 10.06.2011.

\section{Conclusions}

Starting in the 1950s, Japan paved the road for the economic growth of some of the most important countries in Asia, "the Asian dragons or tigers", completed with China, Vietnam, Pakistan, Bangladesh and India.

Most of the successful Asian countries combined the following factors as a recipe for success: capital accumulation, efficient allocation, rapid technological progress, macroeconomic stability, high investments in human capital, stable and secure financial systems, limited price distortions, strong institutions, openness to foreign technology and foreign investments and exports. Human capital accumulation offered the chance for Western technologies to be absorbed and constantly improved.The Asian countries imported from the western countries the knowledge and technologies, but never the ethics. They promoted in business their own values and the results are nowadays visible.

The new international division of labor found Asian countries prepared to take over the outsourced industries of the developed countries and become major actors in world markets.

Though Amartya Sen questionied authoritarian regimes influence in the economical success or failure of various Asian countries, I think that what is more important, is the leadership style and 
the fact that Asian leaders have followers. One major cultural difference between Western and Asian countries is that in the Asian countries, emphasis is placed on collective values while in the Western countries, the emphasis is placed on individual values.

Some of the Asian countries are rich in natural resources and this alone is a booster of economic growth or instability,depending on other countries interests in the area.

Maybe the Cold War and the fight for influence in the region also represented one of the drives of this miraculous growth, as was the influence of the US over Japan during the Korean War and then the Vietnam War, but those influences were the kick start for the growth to come.

Whatever the reasons, there are some countries in Asia which made their impact on economy at a global scale and continue to provide international markets with quality products and services. We all know about Sony, Toyota, Samsung, Daewoo, LG, Kia, Hyundai etc. When we look at a nice picture, we assume that it might have been taken with a Canon or Samsung camera. When we watch TV, most probably the make is a Sony or Samsung or LG and so on.

\section{Risks}

However, new downside risks have emerged:

- the potential for higher oil prices, particularly due to unrest in the Middle East, which could disrupt global growth and fuel inflation; asset prices.

- overheating risks in many Asian economies in terms of both consumer price inflation and

There are two priority issues to strengthen the platform for sustained strong growth in Asia. Policies to increase domestic demand and boosting infrastructure investments. Promoting more inclusive growth will also help make growth more sustainable, since we can still find in some countries extended poverty, high inequality and youth unemployment.

We don't know the future, but as an old Chinese proverb says, "may we live in interesting times", interesting economic times.

\section{References}

1. Bosworth B., Collins S., Virmani A., 2007. Sources of growth in the indian economy, Working Paper 12901, p. 24.

2. Chidambaram P., 2007. India's Economic Growth and Outlook, available on-line at http://www.iie.com/publications/papers/paper.cfm?ResearchID $=810$, visited on $12^{\text {th }}$ of June 2011.

3. Holz A. Carsten, 2005. China's Economic Growth 1978-2025: What We Know Today about China's Economic Growth Tomorrow, available on-line at http://129.3.20.41/eps/dev/papers/0512/0512002.pdf, visited on the $11^{\text {th }}$ of June 2011.

4. Hays J., 2009. Japan's economic miracle and the 1950s, 60s, and 70s, available on-line at: http://factsanddetails.com/japan.php?itemid $=524 \&$ catid $=16 \&$ subcatid $=110$, visited on the $7^{\text {th }}$ of July 2011.

5. Krugman P., 1994. The Myth of Asia's Miracle, Foreign Affairs, Nov/Dec 1994, Vol.73, Iss. 6, p.67, p. 71.

6. Sang-In Jung, 1999. No (Logical) place for Asian values in East Asia`s Economic Development, Development and Society, Volume 28 Number 2, p. 192.

7. Sen Amartya, 1997. Human Rights and Asian Values, The New Republic, July 14-July 21, p.1.

8. Singh Anoop, 2011. The next Phase of Asia`s Economic Growth, available on-line at http://blog-imfdirect.imf.org/2011/04/28/asias-next-economic-growth-phase/, visited on the $6^{\text {th }}$ of July 2011. 
9. Stiglitz E. J., 1996. Some lessons from the East Asian miracle, World Bank Res Obs 11(2), p. 151 , p. 153.

10. Krasilshchikov V., 2006. The East Asian 'Tigers': Following Russia and Latin America? available on-line at http://www.caei.com.ar/es/programas/asia/17.pdf

11. Xie Andy, Ahya Chetan, 2004. India and China: A Special Economic Analysis, New Tigers of Asia, Morgan Stanley, available on-line at http://www.nexthorizon.info/infocenter/MorganStanleyNewAsiaTigers.pdf. visited on the $10^{\mathrm{th}}$ of June 2011.

12. Xinhua, 2007. Four factors bolster China's economic growth, available on-line at http://www.chinadaily.com.cn/bizchina/2007-06/18/content_896806.htm, visited on the $13^{\text {th }}$ of July 2011.

13. http://www.galbithink.org/topics/ea/save.htm, visited on $12^{\text {th }}$ of July 2011.

14. Kazakhstan to bolster economic growth by slashing red tape, available on-line at http://centralasianewswire.com/Kazakhstan/viewstory.aspx?id=4010, visited on $9^{\text {th }}$ of July 2011

15. (3) http://mg.co.za/article/2010-12-24-a-new-decade-economic-growth-and-opportunitiesfor-kazakhstan.

16. (4) http://www.state.gov/r/pa/ei/bgn/4130.htm, visited on $11^{\text {th }}$ of July 2011. 